\title{
Ethical Perspective on Turkish Environmental Impact Assessment for Nuclear Energy
}

\author{
Hayrettin Kilic \\ The Green Think Tank of Turunch Foundation, Hoboken, NewJersey 07030, USA
}

\begin{abstract}
In 2013, The Turkish Ministry of Environment and Urban Planning issued four thousand pages of a cut and paste Environmental Impact Assessment (EIA) report for the Akkuyu nuclear power plant and nuclear fuel fabrication complex project located on Turkey's Mediterranean coastline, in the Mersin providence, which will be built on a build-own-operate basis by Russian company Rosatom. Numerous complaints have already been filed against the EIA, challenging the scientific integrity of the report on the following grounds: misrepresentation of failure to specify the radioactive inventory and of projected releases into the environment, omitting tritium and carbon-14; incomplete information about the toxic chemicals which will be injected into the cooling system throughout the nuclear complex; misleading information about the cooling water's temporal and chemical effects on marine life; lack of details on an emergency evacuation plan; lack of a comprehensive nuclear waste management plan; unspecified insurance coverage for the nuclear complex, noncompliance with third party liability requirements. Coupled with these complaints are allegations that signatures on some sensitive reports contained or referred to have been falsified.
\end{abstract}

Key words: Turkish Nuclear Energy Project, Environmental Impact Assessment.

\section{Introduction}

On December 11, 2013, The Turkish Ministry of Environment and Urban Planning issued three thousand pages of a cut and paste Environmental Impact Assessment (EIA) report for the Akkuyu nuclear power plant and nuclear fuel fabrication complex project located on Turkey's eastern Mediterranean coastline, in the Mersin providence, which will be built on a build-own-operate (BOO) basis by Russian company Rosatom [1].

The Akkuyu-EIA is a critical document to the licensee as well as to all stakeholders. It is intended to identify and assess all the environmental and socio-economic impacts of a 4,800 MWe nuclear power plant. However, the report approved by the Turkish Government failed to provide a comprehensive assessment of establishing and clearly identifying with scientific integrity, the likely impacts of this project in the region.

Corresponding author: Hayrettin Kilic, Ph.D., research field: nuclear energy and environment.
To have any legitimacy of an EIA, it must be prepared truthfully, transparently, independently and any issues that arise must be discussed openly and resolved in public meetings and approved by local communities before it is finalized. But local people living in the Akkuyu area and Mersin who are opposed to the Akkuyu project were prevented by police from participating in the public hearings.

So far, numerous complaints have already been filed against the Ministry of Environment and Urban Planning in the Mersin High Court. These complaints seek to challenge the scientific integrity of the EIA report on the following grounds: misrepresentation of failure to itemize the radioactive inventory and projected releases into the environment, omitting tritium and carbon-14 isotopes; incomplete information about the toxic chemicals which will be injected into the cooling system throughout the nuclear complex; misleading information about the cooling water's temporal and chemical effects on marine life; lack of details on an emergency evacuation plan in case of a sewer accident; lack of a comprehensive nuclear 
waste management plan; unspecified insurance coverage for the nuclear complex as well as noncompliance with third party liability requirements. Coupled with these complaints are allegations that signatures on some sensitive reports contained or referred to in the EIA, which have been falsified.

The aim of this paper is to shed a light on inefficient and irresponsible radiation protection assessments for Akkuyu nuclear energy complex. Turkish Atomic Energy Authority (TAEK), current promoter and safety regulator of nuclear energy in Turkey, has no effective organizational power and scientific capacity to make independent rules and enforce compliance or impose international safety measures during the constructionoperation, and has no legal rights to control Russian built-operate-ownership domination at the Akkuyu project.

Within the frame work of global view and according to the latest IAEA's relevant document: "IAEA ENVIRONMENTAL IMPACT ASSESSMENT FOR CONSTRUCTION AND OPERATION IN NEW NUCLEAR POWER PROGRAMMES" [2]. The process of conducting an EIA for a nuclear power project is, in many respects, quite similar to other industry EIAs. This section examines the issues that are unique to the experience of an embarking State conducting such an assessment. Nuclear power technology possesses unique characteristics that affect the environment, such as routine and accidental radiological releases, principally to air and water. Specialized techniques for modeling these potential releases have been developed, with particular methodologies for impact assessment. Radioactive waste and spent fuel management is also specific for a nuclear EIA, and would need to be addressed, despite the fact that separate EIA reports will be required. As part of the baseline environmental data collection programmer, radiological measurements need to be made. Radiological monitoring is also required throughout operation and decommissioning.

The environmental impact assessment is a trans-boundary document recognized by the members of Espoo Convention that is known as the United Nations Convention on Environmental Impact Assessment. Therefore, an international hearing procedure pursuant to the Espoo Convention must also be executed in connection with a given nuclear power plant (EIA) procedure. According to the Espoo convention, licensee/operator of the nuclear power plant is liable to compensate for damages caused by the nuclear event/accident at the nuclear facility, and responsible for compensable trans-boundary damages in the neighboring countries including but not limited to personal injuries, damage to property, financial loss, and the costs of environmental restoration measures and damage prevention measures.

"The Convention was adopted in 1991 and entered into force on 10 September 1997. The Espoo Convention sets out the obligations of parties to assess the environmental impact of certain activities at an early stage and every indeed stage of planning. It also lays down the general obligation of states to notify and consult each other on all major projects under consideration that are likely to have a significant adverse environmental impact across boundaries" [3].

Therefore, within the frame work of global Espoo convention, parties to the Convention have the right to take part in an environmental impact assessment procedure carried out in Turkey, if the country in question is potentially affected by the adverse environmental impacts of the project to be assessed. Correspondingly, Turkey has the right to take part in an environmental impact assessment procedure of a project located in another country if the project may affect Turkey. Moreover, while developing a comprehensive nuclear power plant EIA report, which would be fitting to an IAEA's member country's existing legislative framework or policy, it is also important that a strict adherence observed with existing IAEA's guidelines [4]. More specifically, it must be consistent with IAEA Nuclear Energy Series No. NG-G-3.1. 
Although Turkey has been a member of the United Nations Economic Commission for Europe (UNECE) since 1947, Turkey has neither signed nor ratified the Espoo or Aarhus Conventions. Especially with regard to the Espoo Convention, given the tensions that exist in the Middle East region, full implementation of the requirements of a Trans-boundary environmental agreement would not be fully feasible at this time.

The technical part of an EIA must include a contribution of individuals and groups drawn from all relevant disciplines. Physicists, chemists, sociologist and a variety of engineers contribute to the sa0fety analysis of the design and construction phases of the nuclear facility. Moreover, The EIA report must present the analysis and findings of the process in a complete manner with upmost scientific integrity.

Ideally, it must be conducted by an independent, internationally recognized organization, free of political pressure from the state implementing the project. It should describe every facet of the safety problem and the baseline of the environment and surrounding population, identifying significance of the impacts of the project in all its phases on the ecosystem and inhabitants. A nuclear complex's EIA must also include a well-planned emergency and monitoring program for necessary prompt mitigating measures when the monitored impacts exceed design expected limits of a nuclear power plant.

\section{Routine Releases of Radioactive and Toxic Materials from a Nuclear Power Plant}

The last 60 years of experience in nuclear age, civilian or military, have proved that the extraordinarily poisonous nature of radioactive materials involved and produced in a nuclear industry facility. Even small quantities of radioactive material or waste released into the environment can have irreversible and devastating effects on ecosystems. Some of the radioactive materials found in a nuclear reactor are a million times more toxic than chlorine.

Therefore, IAEA guidelines and the State regulations limit the total amount of radioactive materials released from nuclear power plants during normal operations. Although, an internationally adapted limit is set, but hardly followed or implemented in different countries, so that no member of the public would receive a radiation dose greater than 0.1 rem annually from the radioactivity released to the environment from all pathways in the form of gas, liquid, or solid. However, the amount of radiation doses that the public can be exposed to over a certain period of time, have been subject to superficial changes by the nuclear regulatory authorities and varies in different countries, ranging from 100 to 200 milli-rems a year.

Hence, the nuclear complex operators must monitor all potential pathways by which radio-toxic materials that could be released from the facility, determine the amount of radioactive emissions on continuing basis, and must manage those emissions so that a member of the public would not receive an annual dose more than permitted limits, and in case of major event or accidents, inform the national and international authorities.

Although, the emission limits are separately specified for each component of the nuclear power plant, IAEA guidelines requires that nuclear plants should be designed to provide rigorous control of all radioactively contaminated gases and liquids discharged to the environment during all modes of normal reactor operation. Also, a nuclear power plant must have enough on-site capacity to be able to store radioactive liquids and gases, when the schedule release of these materials is impaired due to natural disasters, during the abnormal atmospheric conditions, hurricanes, earthquakes.

\section{Unique Issues in the Akkuyu Nuclear Power Plant Environment Impact Assessment}

\subsection{Geopolitical Concerns}

In July 2010, Mr. Erdogan, who was then the Prime Minister, concluded an intergovernmental agreement 
with Russia involving the transfer of nuclear energy technology to Turkey. A $\$ 20$ billion contract was signed with the Russian company Rosatom to build a nuclear power plant and possibly a fuel fabrication complex at the Akkuyu-Mersin. There can be no clearer indication that, these intergovernmental projects are geopolitically motivated and will provide a new breeding ground for nuclear weapon programs thinly disguised as "Nuclear Technology Transfer Agreements". The latest attempts by Turkey, the Arab Emirates, and Jordan to embark on vigorous nuclear programs collectively show that the proliferation of nukes in the Middle East is now the greatest challenge.

Under the new nuclear energy legislation passed by the Turkish government, a new Atomic Energy Commission (AEC), directly controlled and staffed by the prime minister, was established to oversee all future nuclear activities in Turkey. Worryingly, the budget, plans and programs of the AEC cannot be questioned or challenged without the consent of the Prime Minister. And to make absolutely sure that he has complete control over the workings of the AEC, President Erdogan has appointed his son in law Mr. B. Albayarak as the minister of the Ministry of Energy and Natural Resources of Turkey.

The AEC is also charged to govern the Turkish Atomic Authority (TAEK) programs, which in turn is both the promoter and safety regulator of the nuclear energy industry in Turkey. In fact, both organizations are politically subordinate to the Prime Minister's office and have no effective organizational power, scientific expertise or capacity to make independent rules, enforce compliance or impose international safety measures during both the construction and operational phases of the nuclear complex in Akkuyu.

When complete, the Akkuyu site will be the first and only nuclear power complex in the world under the control of an operator that is a subsidiary of a foreign rather than sovereign State from construction through to the end of undetermined decommissioning process.
Furthermore both cooperation agreements also include the possible establishment of foreign owned and operated nuclear fuel cycle programs, more specifically nuclear fuel reprocessing and fuel fabrication facilities in Turkey. And, so the very real possibility arises, of weapon grade nuclear material being manufactured by Russia within the borders of a member of the NATO alliance.

\section{Major Arguments against Validity of Approved Akkuyu EIA Report}

\subsection{Misrepresentation of or Failure to Itemize and Specify the Radioactive Inventory and Projected Rad-gas Releases-emissions into the Environment}

Routine radioactive gas and liquid releases, and the disposal of radioactive waste require a full understanding of its radioactive content in terms of the concentration and types of radionuclides. The EIA report approved by the Turkish Government failed to provide a comprehensive inventory of the isotopes that will exist throughout the complex during its normal operation, and completely failed to address Tritium and Carbon 14 isotopes, the two major isotopes which, between them, contribute more to releasingradiation into the environment than all of the other 23 isotopes combined.

Radioactive gases and toxic- contaminated gases, are routine byproducts of nuclear power plant operation, which are created by fission and neutron activation processes. In pressurized water reactors (PWR), radioactive gaseous, such as Tritium, Carbon, Argon, Krypton, Iodine, Xenon, Iodine and Cesium are produced in various forms of isotopes mostly in the high pressure moderator-cooling-water, fuel assemblies and spent fuel pools. During the normal operation, these radioactive gaseous, at significant amount of tritium and carbon-14, are removed from the reactors core and transferred to on-site tanks, so that they can be released through a vent pipe to the atmosphere, within the permissible levels which are determined by a given state regulator. 
The EIA report, produced by a private Turkish company so called Dokay [1], and approved by Turkish government on December 2014, which includes the amount of annual radioactive release shown in section V. table V.2.8.5 of the EIA report. This table indicates that the four units, 4,800 MWe, a total annual routing release of 23 radionuclides is $1.02 \times 10^{\mathrm{e} 14}$ Becquerel, corresponding to total 2,756 curies, annually 689 curies for each reactor.

Based on the original August 1977 the US Oak Ridge National Laboratory report ( page 12, table 2.5) indicates that annual air-born releases from a 1,000 MWe PWR is about 13.935 Curie, 1,100 curies of which is tritium, mostly in gas form [5].

Ironically, in Turkish EIA, Table V 8.5 does not include two very important isotopes, namelyTritium and Carbon C-14 isotopes, and total annual releases from four VVER-1200 reactors is 2,756, which is almost 20 times less that actual releases. $\mathrm{T}$ and $\mathrm{C}$ Somehow were omitted or simply do not exist in the Akkuyu nuclear power plant project. This is an undisputable exhibition $\mathrm{A}$ in any court of law, showing that the EIA approved by Turkish government has no scientific integrity, therefore this cut and paste EIA must be terminated.

\subsection{Lack of A Comprehensive Nuclear Waste Management Plan}

A more specific description of the nuclear waste management program that a long-term sustainable and environmentally safe disposal of spent nuclear fuel must be ensued before a new nuclear power plant is to be built. The environmental impact assessment of the Akkuyu project does not include a clear description of the development of Akkuyu's spent nuclear fuel management plans in general, and, does not include any assessment of the final disposal of spent nuclear fuel in particular. Plans on arranging nuclear waste transportations routes from the Akkuyu site to Russia or any other destination, and that whether Russian-Rosatom or Turkish-Taek will be responsible for any accident during the transportation are not specified.
In the Akkuyu complex, between refueling periods, about every two years, average solid waste generated from a 4,800 MWe PWR plant will be: 180 tons of spent nuclear fuel and 200 tons low-level radioactive waste, including personal protective equipment, spent resins beads, filters. The EIA program includes very little information about how and how long Rosatom intends to treat and keep the spent nuclear fuel on the site. There is no clear plan on verifying the safety of interim storage and final disposal of nuclear fuel. And most importantly, what will happen, if Rosatom decided to cancel operation after 15 years.

\subsection{Incomplete Information about the Toxic Chemicals Which Will be Used or Injected into the Cooling System throughout the Nuclear Complex}

Boric acid is used as a neutron absorber in the primary coolant of PWR reactors. It can be used in some support systems at the spent fuel pool-storage areas. Hydrazine is used in the component intermediate cooling system for deoxidization and corrosion prevention. Ammonia is used in the feeding water system to control the $\mathrm{pH}$ value of the water. Lithium hydroxide is used in the primary circuit to control the $\mathrm{pH}$ value. Sulphuric Acid $\left(\mathrm{H}_{2} \mathrm{SO}_{4}\right)$ is used in demineralization as a recovery chemical of the ion exchangers. Sodium hydroxide is used as different solutions.

The Akkuyu EIA report has failed to identify and quantify any/all of the chemical substances that will be used during the normal operation of a nuclear power plant. Considering the average temperature of atmosphere and sea temperature whose reach has over 30 Celsius degree in Akkuyu region, the EIA report did not provide vaporization rates of the toxic chemicals and adverse health hazards in the surrounding population.

\subsection{Misleading Information about the Cooling Water'S Temporal and Chemical Effects on Eastern Mediterranean Sea Marine Life}

The Mediterranean Sea comprises less than $1 \%$ of the world's oceans, but it contains about $7 \%$ of all 
known marine species, including 357 species of reptiles, 115 amphibian species, 400 species of fresh water fish, and 22,500 endemic vascular plants species [6]

Akkuyu is located on the northeast corner of the Mediterranean Sea where the average surface sea water temperature is higher than the atmospheric temperature for at least 6 months a year. It will be the first nuclear power plant using cooling water that has a very high salinity of $39 \%$ and with temperatures reaching 30 Celsius or higher during the summer months.

Ecological effects of a nuclear power plant on local marine life, as well as the long-term geopolitical consequences, have been generally overlooked and the Turkish EIA is no exception. Each day, more than 3 billion gallons of sea water will be circulated through the power plant; this process will change the temperature/chemistry of the north eastern corner of the Mediterranean Sea and will kill billions of larvae and juvenile fish. Within 10 years local marine life will be destroyed as previously happened in California.

According to a California State official report, "Ironically, with all of thelimitations and prohibitions placed on discharges, impingement and entrainment have essentially constituted a permitted fish kill for power plant intake systems". "The reality is, however, that a power plant cooling system does not discriminate and instead causes mortality to all aquatic life in the intake water column" [7].

Of the heat produced in a nuclear power plant, onlyup to 35 percent can be converted into electrical energy. Due to this, part of the heat produced must be removed from the power plant by way of condensation. The condenser is cooled using water taken directly from nearby sea, lakes or rivers. The cooling water consumption will vary depending on the reactor cooling systems' design and the amount of energy produced. A 1,000 MWe PWR nuclear power plant with open cooling system will require approximately $40-45 \mathrm{~m}^{3} / \mathrm{sec}$ of seawater to cool the condensers.

The temperature of cooling water, after being circulated within the complex, rises by $10-12{ }^{\circ} \mathrm{C}$ in the process; this will then be discharged back into the sea. In addition to chronic radioactive gas releases every day, enormous quantities of water, 10 billion liters per day, will be circulated throughout the Akkuyu nuclear complex destroying billions of larva and other marine creatures, including planktonic organisms.

Discharged cooling water which includes all the toxic chemicals used or injected throughoutthe nuclear complex will change the chemical composition of localsea waterand also increase the temperature. The average temperatures in Eastern Mediterranean Sea is over 30 Celsius during the summer months, which will reach to over 40 Celsius degree in Akkuyu Bay as result of the discharged cooling water, hampering the cooling capacity of the cooling water system during the hot summer months, and will make the four reactors unable to operate in maximum capacity.

The Fukushima accident become a lingering global disaster as a result of destroyed cooling systems and proved that the cooling water is the most significant part of the operation of the nuclear power plant. The modeling of the open cooling system designed for the Akkuyu power plant and the modeling methods are not realistic and are incomplete. Biodiversity of underwater habitats and species in the immediate vicinity of the Akkuyu has not been assessed. Calculations regarding cooling water circulation intake and discharge rates are not conservative, and uncertainties in modeling methods are not clearly illustrated.

\subsection{Lack of Details on an Emergency Evacuation Plan in Case of Sewer Accidents}

According to scientific reports submitted to Mersin High Court, the safety risks caused by the fact that the Akkuyu nuclear power plant site is low-lying on non-rock hard ground and are located only a few miles from unstable seismic faults. The Akkuyu IEA report failed to describe in detail how residential areas are located in the immediate vicinity of the plant site and which are the closest vulnerable sites, such as schools, day-care centers, tourism related 
establishments and hospitals.

There are no studies on the project's impact on welfare of local residents, business life, safety, and society. Further, those radioactive releases of a severe reactor accident will spread over a very wide area in the Middle Eastern region. The fact that the atmospheric assessments in the EIA report are limited to a distance of about $1,000 \mathrm{~km}$ due east and west from the Akkuyu site is inadequate, and the modeling on geographical spreading of radioactive substances should be expanded in all direction.

4.6 Unspecified Insurance Coverage for the Nuclear Complex and Noncompliance with Third Party Liability Requirements

According to International conventions and IAEA guidelines, the licensee of the nuclear power plant must have insurance covering third party liability including neighboring countries. However, neither "Nuclear Technology Transfer Agreements" singed by Turkish and Russian governments, nor EIA report clearly specifies as to which party is liable to compensate for damage caused by a nuclear event at the nuclear facility, regardless of whether the licensee is actually responsible for the occurrence of that damage. Compensable damage includes personal injuries, damage to property, financial loss, and the costs of environmental restoration measures and damage prevention measures.

For Example, the licensees of nuclear facilities located in Finland have unlimited liability for nuclear damage caused by a single nuclear event in Finland. The liability of the licensees of nuclear power plants located in Finland for nuclear damage caused outside Finland is limited to 600 million Special Drawing Rights of the International Monetary Fund, corresponding to approximately EUR 676 million.

4.7 Incomplete Study of the Project'S Foreign Goods and Services Impacts During 15-20 Years of Construction Time on Local Society and Employment

The new intergovernmental Nuclear Cooperation
Agreement between Turkey and Russia is an ill-advised and poorly crafted document that is devoid of any transparency. Not only does it essentially block the Western nuclear industry from Turkey, but it also fails to involve Turkey's own scientists and engineers. Indeed, Turkey's own industry is effectively deprived of any benefit from this $\$ 20$ billion project. The Russian Rosatom and its subsidiary corporations will control $100 \%$ of the stock. In accordance with the new cooperation agreement, Rosatom will be permitted to use Russian goods and materials, workers, and services to build and operate the reactors for 60 years.

\subsection{Scandals Surrounding the Stakeholder Hearing Procedure}

The EIA procedure is an open process in which all residents and other stakeholders including neighboring countries can participate. One of the key goals with this interaction is to gather the views of different interested parties and utilize them during the EIA procedure. Moreover, parties to the Espoo Convention have the right to take part in an environmental impact assessment procedure carried out in Turkey if the state in question may be affected by the adverse environmental impacts of the project to be assessed.

The EIA is supposedly subject to independent public hearings and approval before it will be finalized. The Turkish government repeatedly blocked or canceled the public hearing participation process when the majority of the participants were against to the Akkkuyu project. Instead, they brought members of their party from nearby cities by bus to be present in several pre-approved public meetings in Mersin Province.

The NGO's and hundreds of peoples' representatives living in the Akkuyu area and Mersin who are opposed to the Akkuyu project were prevented by police from participating in these pre-approved public hearings. After 30 days of a largely superficial review process, the Prime Minister, Mr. Erdogan, sent a letter to every governmental institution involved asking them to expedite their final approval of the EIA. A revised version of the EIA was approved by the AK 
government on April 10, 2014, a day before president Putin's visit to Turkey.

4.9 Economic Impact of Compulsory Electric Energy Purchase Agreement between Rosatom and Turkish Electrical Trade Contracting Co. Inc. (TETAS)

The Turkish Electrical Trade Contracting Co. Inc. (TETAS) has guaranteed that it will purchase $70 \%$ of the electrical energy generated from 2 of the 4 reactors during the first 15 years of operation at a weighted average price of $12.35 \mathrm{US}$ cents per $\mathrm{kWh}$. The other two reactors will obviously be used to power the nuclear reprocessing plant or sell the electrical energy in open market at an undetermined and uncountable rate.

But, after the first 15 years of operations, there is a tremendous uncertainty as to what will happen. Energy economists, however, agree that the provisions of Article 10 of the agreement signed by Turkish and Russiangovernments (which outlines the power purchase portion of the accord) guarantee the Russians a speedy and lucrative return on their investment. In fact they will enjoy a $\$ 50$ billion, or more, return of their capital investment within 15 years.

\subsection{Misleading Presentation of the} Rosatom-company's Nuclear Power Competence

Counterfeit equipment has been a major threat to nuclear safety globally. Over the last three decades, while the Russian nuclear industry attempts to enter into the world nuclear energy market, its business practices as experienced in Bulgaria, Iran, India and China are well documented. Corruption relating to reactor materials and components often being supplied from unknown origins has caused long delays and even project cancelation.

There have been well documented and repeated failures of the Russian-built nuclear power plants in Eastern Europe, Iran, Chine, and India. The VVER-1200 reactors do not meet European safety standards and are untested and unproven in the western world. In Iran, Busherh nuclear reactor's main circulation pumps failed during startup operation, the Kudanku-lam Nuclear Power Plantin India housing two VVER-1000 reactors, built by Russia has been delayed almost 10 years, because of counterfeit, substandard and obsolete equipment. In fact, Kundankulam power plant's turbines failed during the startup operation.

\subsection{Corruptions Remain Endemic in Russian Nuclear Industry}

With huge resources and unconditional Russian federal state support at its disposal, the Rosatom, acorporation of anoverlap between a state organization and a privately owned company, and its subsidiary nuclear industries, remainsalmost immune to any international control. The lack of transparency, widespread corruption, and failure todemonstrate high levels of safety, and the unresolved nuclear waste and dozens of deserted nuclear reactors decommissioning issues in Russia must be of high concern to the Turkish government.

Eco-defense and Transparency International Russia's investigation conducted in 2010, demonstrated that the order-placing activities of Rosatom companies are exposed to high corruption risks. Furthermore, the study found that, purchasing activities of sensitive equipment does not meet the ISO standards.

Several years after the study was published more than 270 Rosatom employees were fired over corruption allegations. Several cases involved top officials, one as high-ranking as a deputy director. In July 2011, Rosatom's former deputy general director, Yevgeny Yevstratov, was arrested on suspicion of embezzling 50-million roubles (\$1.7-million). The charges were related to a series of incidents of large-scale fraud that investigators said took place at Rosatom and its nuclear fleet subsidiary, Atomflot, under Yevstratov's supervision.

\section{Conclusion}

On July 21, 2016, the primary court hearing was held 
at Akkuyu site. By the request of the court, Turkish government appointed fifteen scientists, comprising different disciplines of engineering, from various government universities, who were charged to determine the validity of the EIA and report to the court accordingly. On the complaints side, the attorneys representing the Union of Turkish Bar Assosiation, the Union of Chambers of Turkish Engineers and Architects (UCTEA), including twenty four engineering disiplens, theTurkish Medical Assosiation, and seven NGO'spresented thier case against to the EIA report. They vigirously argued regarding to the impertiality of the goverment employed experts.

And thereby demand that the Turkish government should suspend and cancel all permits, as they relate to the issuance of pre-construction permits and activities until an independent internationally recognized organization has produced a complete Environmental Impact Assessment Report. One that includes the latest international safety standards and public input, and as well as the criteria's of the relevant conventions, explicitly the Specially Protected Areas of Mediterranean and Black Sea (SPAMs). It has been pointed out that, it is of paramount importance that the Turkish government experts carefully reassesses all the documentation regarding these projects, including, but not limited to, the 35 year old, outdated, ill-crafted site-license, site evaluation, and any non-credible Russian designed VVER-1200 reactor certifications.

All the thirteen complaints filed against to the existing EIA in Mersin High Court stated that before Akkuyu-Mersin, officially becomes an integral part of the Russian disarrayed nuclear industry installations, which has been omitted by their own nuclear regulatory commissions, they strongly urge to the experts of the High Court of Mersin to immediately invalidate the existing EIA report. This will be the first step to stop imposing unsafe and expensive nuclear energy on Turkish people and create unforeseen geopolitical and ecological uncertainties in the Mediterranean Sea regions.

\section{Acknowledgement}

The author would like to thank to Mrs. Marry Jimenez for her valuable comments.

\section{References}

[1] Republic of Turkey Ministry of Environment and Urbanization. "4.800 MWe Kurulu Gücünde Olan Akkuyu Nükleer Güç Santralı Projesi (Nükleer Güç Santralı, Radyoaktif Atık Depolama Tesisi, Rıhtım, Deniz Dolgu Alanı ve Yaşam Merkezi).” Dokay Enviromental Engneering Ltd. Accessed August 20, 2016. http://www.csb.gov.tr/db/ced/editordosya/Akkuyu_NGS_ CED_Raporu.pdf.

[2] The International Atomic Energy Agency. 2014. Environmental Impact Assessment for Construction and Operation in Nuclear Power Programs. IAEA. Vienna, Austria.

[3] Bastmeijer, C. J. and Koivurova, T. 1991. "Convention on Environmental Impact Assessment in a Trans Boundary Context." The Espoo Convention. Accessed August 20, 2016. http://www.unece.org/mission.htmlhttp://www. unece.org/env/eia/eia.html.

[4] The International Atomic Energy Agency. 2007. Milestones in the Development of a National Infrastructure for Nuclear Power: A Status report. IAEA. Nuclear Energy Series No.NG-G-3.1 report.

[5] McBride, J. P., Moore, R. E., Witherspoon, J. P. and Blanco, R. E. 1977. "Radiogical Impact of Airborne Effleuts of Coal Fired and Nuclear Power Plants." Oak Ridge National Laboratory. Accessed August 20, 2016. http://web.ornl.gov/info/reports/1977/3445605115087.pdf.

[6] Bazairi, H., Ben Haj, S., Boero, F., Cebrian, D., De Juan, S., Limam, A. et al. 2010. The Mediterranean Sea Biodiversity: State of the Ecosystems, Pressures, Impacts and Future Priorities. UNEP. Tunis, Tunisia.

[7] Waters, E. 2008. Water Quality Control Policy on the Use of Coastal and Estuarine Waters for Power Plant Cooling: Scoping Document. A document of State Water Resources Control Board. 